Quarterly Journal of Economics and Economic Policy

2014 VOLUME 9 ISSUE 2, June

p-ISSN 1689-765X, e-ISSN 2353-3293

www.economic-policy.pl

Sachpazidu-Wójcicka K. (2014), Conditions for Innovativeness of Industrial Entrepreneurs in Poland, "Equilibrium. Quarterly Journal of Economics and Economic Policy", Volume 9, Issue 2, pp. 93-107, DOI: http://dx.doi.org/10.12775/EQUIL.2014.013

\author{
Karina Sachpazidu-Wójcicka*
}

University of Biatystok, Poland

\title{
Conditions for Innovativeness of Industrial Entrepreneurs in Poland
}

\section{JEL Classification: $O 30$}

Keywords: Innovativeness, technology transfer, innovation activity

\begin{abstract}
Strong competition among entrepreneurs forces them to use innovation as the main source of competitive superiority. Dominating role of innovation - the factor of development - forces individual firms to search for the capability of widest use of innovation in their activity. Innovation is a result of specific process, which links up operations like presenting an idea of innovation and implementation of new solution. Proficient management of implementing the innovation process becomes important in creating innovativeness of the company. In order to be able to compete, firms must introduce new technologies, products, services and organizational systems. Nowadays innovation activity driving at bringing new products, processes, new organizational and marketing methods out is one of the most important conditions of firm market success. The paper discusses the concepts of innovativeness and analyses the theoretical conditions for its development, as well as the existing conditions for innovativeness of industrial enterprises in contemporary Poland. The objective of this paper is an analysis of statistical data (GUS) related to technology transfer of industrial entrepreneurs and its influence on innovativeness of firm. This analysis examines the efficiency of innovation activity in Polish industrial companies.
\end{abstract}

(c) Copyright Institute of Economic Research \& Polish Economic Society Branch in Torun Date of submission: March 17, 2013; date of acceptance: December 17, 2013

* Contact: sachpazidu@uwb.edu.pl, University of Białystok, ul. Warszawska 63, 15-062 Białystok, Poland 


\section{Introduction}

Considerable changes occurring in the world of economy indicate a transformation of the traditional economy into the economy based on knowledge, which relies on the highly processed products and advanced technologies. The level of the process advancement to the economy based on knowledge results in the competitiveness of particular enterprises, regions and countries.

Innovativeness belongs to the primary sources of gaining competitive edge. The rhythm of creation and deployment of innovations decides on the competitive edge of Polish industrial enterprises. Companies search for the competitive edge in various areas of activity such as marketing, production, research and development, as well as in the management field. Moreover, the effective management of the processes of innovations deployment seems to be of cardinal importance. Innovative enterprises have to be distinguished by the ability of efficient deployment of innovations in terms of product, process, organization and marketing methods. The experiences of strongly developed countries prove that innovative enterprises are preferred from the level of their internal effectiveness and positive influence on the dynamics of economic development. Furthermore, business companies, in order to survive on the market and increase own competitive edge, have to improve their innovativeness. In the modern economy, creation and rapid spread of innovations within industrial enterprises is considered particularly significant.

As the Global Competitiveness report, prepared by World Economic Forum, displays Poland holds the 41st position in the international competitive ranking (The Global Competitiveness, 2012, p. 13). The current level of innovativeness of the Polish sector of industrial enterprises is insufficient and far from the average presented by the European Union member states. In these circumstances, active operations of enterprises aiming at the reinforcement of the competitive edge through the use of technology transfer mechanisms and conduction of the research-development activities $(\mathrm{R}+\mathrm{D})$ should be launched. The stage of the development of Polish enterprises, particularly small and medium, frequently proves the lack of possibilities of active participation in the process of initiation of innovative activities within the enterprise potential. Companies do not have enough financial and human resources for the conduction of expensive and risky research-development activities. It seems legitimate to state that the only chance to increase enterprises' innovativeness is the transfer of technologies (TT). Within the external technology transfer enterprises can adopt and invest in ready and complete solutions. The acquirement of external technologies is also cheaper and does not require engagement of additional time on its elaboration. 


\section{Methodology of the research}

The source of empirical data within this discourse was COS, European Committee works, as well as national and foreign reports concerning innovativeness. The diagnosis of the enterprises innovativeness background is based on the analysis of the amount of information concerning results of statistics research by the Central Office of Statistics in terms of innovativeness. The researches include industrial enterprises within the Statistics Research Programme of Public Statistics in the topics 1.43.02 - Innovations in the industry. The researches cover 2009-2010. The available choice of enterprises for the research was based on the Polish Activity Classification (PKD) 2007 concerning the sector of industrial enterprises employing over 9 people, with the distinct division into the sectors of small, medium and big enterprises.

\section{Position of the technology transfer in the innovative enterprise activity}

Innovativeness is the result of defined innovative process $-\mathrm{f}$ the chain of activities necessary to accomplish the concept of innovativeness and its alteration into new conditions (Penc, 1999, p. 165).

The innovation process generates new innovative ideas irrespective of the scope of works or the area of innovative activity where it is generated, subsequently creation, design and initial realization of the innovation. The basic meaning, in this sense, is the deployment of new product or solution (Janasz et al., 2001, pp. 194-197).

Innovative process comprises of the range of activities research-scientific oriented, of technical, marketing and organizational character and the ones which lead to elaboration and implementation of new, improved products and processes. Innovations, in this sense, are the result of many complex interactions.

In order for the innovation process take place successfully, it should comprise of the following phases:

- scanning the surrounding (external and internal) in order to identify market and detect various signals;

- strategic choice of options - in order to react on the identified signals;

- allocation of resources to be able to answer the signals;

- implementation of the project commencing with the idea and finishing with the introduction to the market (new product or service) or within the company (new process of production) - aiming at effective answer the signals; 
- learning on the experience, which aims at improvement or alternatively re-innovation - with the exception that this phase is only advised, not obligatory (Jasiński, Ciborowski, 2012, p. 26).

First of all, innovation in an enterprise can be the effect of the researchdevelopment activity within own resources or cooperation with other economic subjects. What is more, innovation processes are frequently accompanied by the technology transfer phenomenon.

The definition of the technology transfer in the subject literature is ambiguous. The technology transfer is a process of technologies exchange among those who possess them and those who require them (Głodek, Gołębiewska, 2006, p. 11). The technologies movement requires the presence of both parties: provider of technologies and their recipients (Lunguis, 2003, p. 267).

From the point of view of enterprises, innovation sources can be divided into internal, received within own research-development works, and external, which means, ready, comprehensive solutions acquired from the outside. The internal sources include own back-up facilities, own laboratories, technical and construction branches, conduction of various national and foreign market research in the range of marketing, promotion etc. stimulation of employees and management staff, creation of the innovative atmosphere in the organization, the use of method of ideas gathering. The external sources include research conducted at universities and research-scientific institutions, know-how, licenses, material technology transfer, scientific conferences with the implementing innovations enterprises, scientific publications, participation in trades and exhibitions, use of consulting companies services (Niedzielski et al., 2007, pp. 13-14).

According to the Central Office of Statistics, the phenomenon of technology transfer should be considered in terms of purchase and sale:

- licenses (excluding licenses for the standard computer software);

- research-development activities;

- automation sources of production processes;

- consulting services;

- other technologies (Nauka i technika, 2012, p.141).

Creation of authorial research-development units and elaboration of technologies occurs within the financial and risk resources possessed by the enterprise. Therefore, those means of acquiring technologies and knowledge elaborations are frequently out of enterprises range, especially for small and medium business entities. At the same time, technology transfer from the outside becomes the realistic chance of improving their innovativeness both in terms of technological innovations and induced non-technological innovations. Technology transfer is an indicator of increasing innovativeness and 
allows the companies for the improvement of their general innovativeness and competitiveness level.

Major differences in the approach to the subject result from the discrepancy in understanding technologies, which is the unique character of the transfer. The technology is usually broadly understood and it covers both material and non-material technologies, technological/information knowledge, which can be transferred by various channels.

According to Oslo Manual Methodology, innovative activity is the entirety of the scientific, technical, financial and commercial activities which lead to deployment of innovations (Zasady gromadzenia i interpretacji..., 2005, p. 49).

Innovation constitutes each technological change used for the very first time in practice, and the company which introduced this change is the innovator. It constitutes main process phase leading to holistic assessment on use of the new products and processes. Innovator introducing the change faces the risks linked to new, not verified process, product or service. After the first use of innovation the process of diffusion commences, during which innovation use is transferred from one company to the next. Innovation spreads in the rhythm depending on the economic predominance of new solution over the old ones (Mansfield, 2002, p. 347).

The definition of innovativeness was initially introduced in the literature by J. Schumpeter, who understood innovation as:

- introduction of the new product which was unknown until this time or the new type of particular product; introduction of new production methods, which were not used in practice in the particular industrial branch and can be perceived as the new invention, or e.g. new trade proceeding with particular goods; opening of new market where the particular industrial branch previously was not introduced, despite the fact if the market existed before or not;

- acquirement of new raw material sources or semi-manufactured goods regardless of whether it existed before or it was just created;

- conduction of new organization of a particular industrial branch (Schumpeter, 1960, p. 104).

The classic division of innovations implemented by enterprises includes technological innovations (material) conducted within a product and process and non-technological innovations (non-material) conducted within organization or marketing methods. 
According to the Oslo Manual formulating methodological standards concerning statistics research in terms of innovations, the following types of innovations can be distinguished:

- products which introduce goods or services which are new or significantly improved in terms of their traits or usage, they include technical, components and material improvement, built-in software, easy use or other functional characteristics;

- processes occurring within the innovativeness process aim at deployment of new significantly improved production or delivery method, this category includes influential changes in terms of technology, equipment and/or software;

- marketing innovations, which aim at implementation of new marketing method connected with significant changes in project/construction or in packaging, distribution, promotion or price strategy;

- organizational innovations, which aim at deployment of new organizational method in the acquired by company rules, in the organization of the workplace or with the relations with the surrounding (Zasady gromadzenia $i$ interpretacji..., 2005, p. 49-55).

Product innovations are focused predominantly on the market needs and they are controlled by customers - recipients behaviours and needs, whereas process innovations are focused on the effectiveness improvement of the production process which results in the efficiency (Waresa, 2012, p.145).

For the needs of the innovativeness analysis within the present article, the division of innovations into product and process was accepted, in accordance with the Oslo Manual. In case of industrial enterprises, the greatest innovations introduced are technological innovations.

The common feature of innovations is the fact that they were actually implemented. New or improved product is introduced on the market. New processes are deployed when they are, in fact, used in the company activities. All innovations have to possess the element of novelty, it can be a novelty on the market scale, world scale or company scale, which is the minimum criterion of innovation existence. (Zasady gromadzenia $i$ interpretacji..., 2005, pp. 49 and 60).

\section{Technology transfer and innovativeness of Polish industrial enterprises}

Polish enterprises occupy one of the last positions in the innovativeness ranking in terms of enterprises participation in the innovative activity, in the general number of companies in the industry (Innowacyjność..., 2010, p. $10)$. 
One of the frequently used indicators of the innovative assessment is the percentage of the subjects deploying product and process innovations. In 2011 among the companies covered by the Central Office of Statistics research, the criterion of innovativeness understood as the deployment of at least one innovation - novelty or significantly improved product or process, was fulfilled by $16,1 \%$ of companies. The percentage of industrial innovative companies decreased from $23,6 \%$ in relation to 2006 . Nowadays, it is possible to observe the regular decrease of the percentage of innovative companies in the industry (see Table 1).

Table 1. Polish innovative enterprises according to introduced innovations in 20062011

\begin{tabular}{|c|c|c|c|c|}
\hline \multicolumn{5}{|c|}{ Innovations in the industrial enterprises } \\
\hline Year & $\begin{array}{c}\text { Innovations } \\
\text { in total (\%) }\end{array}$ & $\begin{array}{c}\text { New or } \\
\text { significantly } \\
\text { improved } \\
\text { products (\%) }\end{array}$ & $\begin{array}{c}\text { New or } \\
\text { significantly } \\
\text { improved } \\
\text { products for the } \\
\text { market (\%) }\end{array}$ & $\begin{array}{c}\text { New or } \\
\text { significantly } \\
\text { improved } \\
\text { processes (\%) }\end{array}$ \\
\hline 2006 & 23,68 & 16,14 & 7,82 & 19,70 \\
\hline 2007 & 37,40 & 28,50 & 14,75 & 25,64 \\
\hline 2008 & 21,39 & 15,57 & 9,39 & 17,18 \\
\hline 2009 & 18,06 & 12,66 & 6,96 & 13,76 \\
\hline 2010 & 17,10 & 12,10 & 6,75 & 12,86 \\
\hline 2011 & 16,10 & 11,23 & 6,12 & 12,36 \\
\hline
\end{tabular}

Source: Own elaboration on the basis of Local Data Bank of the Central Office of Statistics.

The highest contribution of innovative companies was noticed in 2011 in population of big enterprises $57,83 \%$. Among the enterprises employing over 249 people $43,71 \%$ introduced new or improved products, $27,01 \%$ deployed new or significantly improved processes for the market and 48,74\% of companies implemented new or highly improved processes (Figure 1). The subsequent group, in terms of participation of innovative companies, were medium enterprises, where $30,06 \%$ of companies introduced innovation. Small companies demonstrated the worst condition in terms of innovations deployment, only $8,86 \%$ of them implemented innovation. According to the Central Office of Statistics, in 2011 in each class of the enterprise size the percentage of innovative companies decreased in comparison with the previous years. 
Figure 1. Participation of the industrial enterprises deploying innovations with the division into size class and type of implemented innovations (participation of innovative enterprises in \%).

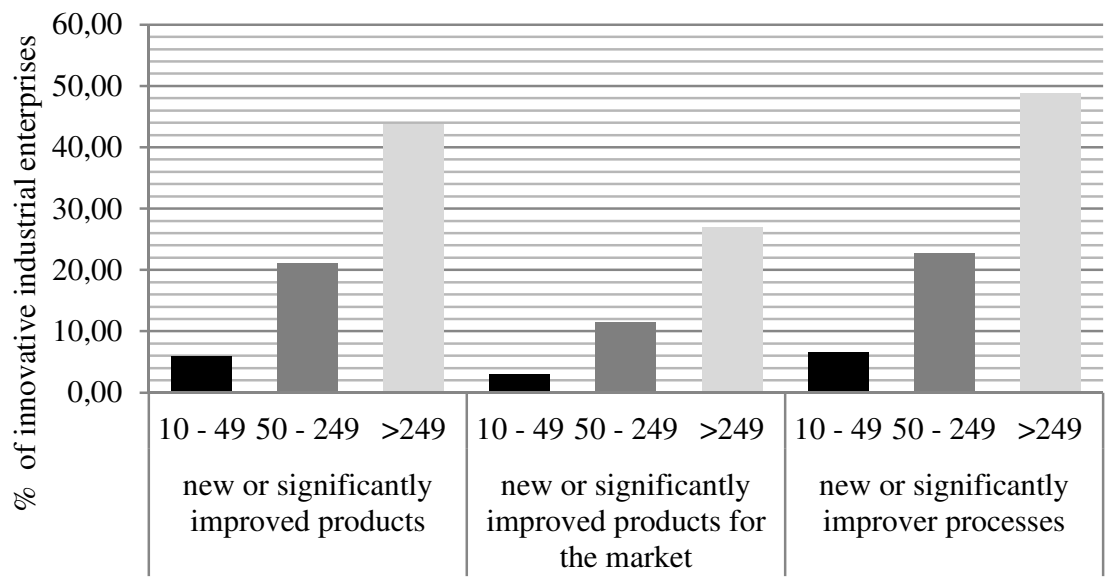

enterprises deploying innovations with the division into size class and type of implemented innovations

Source: Own elaboration on the basis of Science and Technology, Innovative Activity, Local Data Bank of the Central Office of Statistics.

The result of effective innovative activity is the introduction on the market of new or significantly modernized products. Undertaken efforts in terms of innovations decide on the final market success or defeat of new/significantly improved goods or processes. The market answer constitutes a kind of a test which checks if the new product meets the customers' requirements, and verifies if there is a demand for a particular product. Therefore, to a certain extent, the assessment of the innovative activity within the frame of deployment of new products on the market can be analysed by the use of the percentage of enterprises which sell new/highly improved goods, as well as participate in the sale of those goods. What is also noticeable in this range is the decrease of innovativeness of industrial companies. According to the data acquired by the Central Office of Statistics, in 2011 participation in the production of sold new or significantly improved products in the enterprises, the value of sold products, in total, decreased in relation to 2010 in small, medium and big enterprises (Figure 2). In case of this indicator the companies which dominate are the ones which employ over 249 people, with their sale of new or significantly improved goods being the highest. 
Figure 2. Participation in the sale production of goods new/highly improved in the industrial enterprises in the value of the goods sold in total in 2010 and 2011 (participation in the sold production in \%).

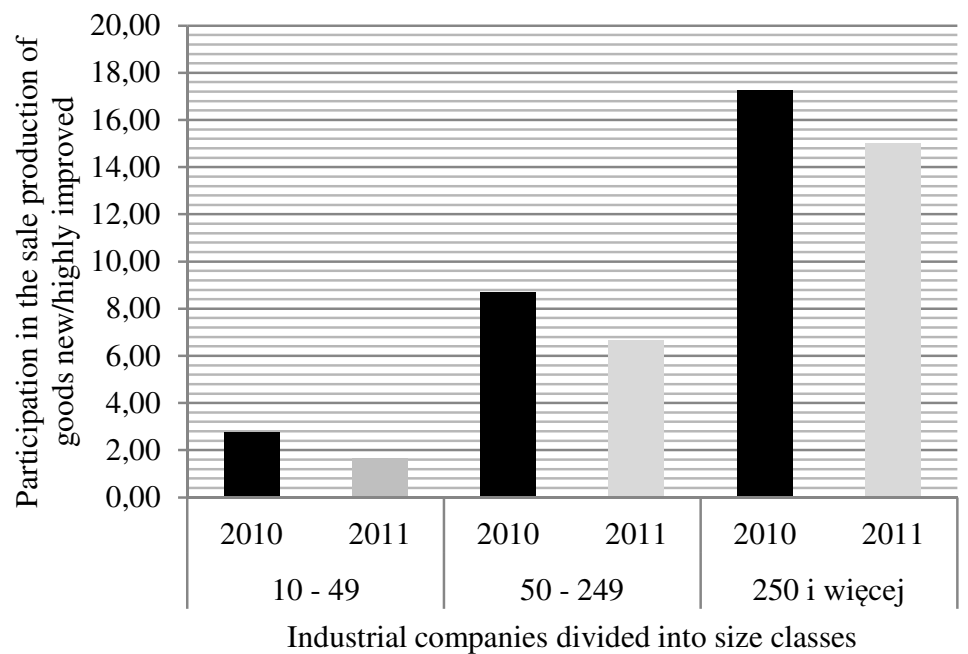

Source: Own elaboration on the basis of Science and Technology, Innovative Activity, Local Data Bank of the Central Office of Statistics.

The decrease of the above indicator means that enterprises generate less income from the sale of products manufactured within innovative activity. In Poland enterprises' innovativeness is measured by the participation of companies, which in the researched period introduced at least one product or process innovation. It also measured the growth of the company taking into account the number of people employed.

One of the key indicators used to measure enterprises innovativeness are the expenses preserved for the innovative activity. The financial resources spend by entrepreneurs are diversified according to the types of activities and sources of financing. In 2011 the expenses on innovativeness of Polish industrial enterprises reached 20,8 billion PLN, including the expenses taken by enterprises employing over 49 people $-93,1 \%$. In the territorial aspect, the highest value of expenses among industrial enterprises were demonstrated by lodzkie and mazowieckie viovodeships. The regions of warminskomazurskie and kujawsko-pomorskie spent the least on innovative operations - on average, one industrial enterprise (Nauka i technika, 2012, pp. 132133). 
In the structure of financial outlays for the innovative activity of Polish industrial enterprises it is possible to notice predominance of the investment outlays, which constituted $80 \%$ of the expenses in 2011 . The majority of the outlays within this category were spent on the purchase of the equipment, technical devices, transport vehicles, tools, appliances, properties and accessories. Only $14 \%$ of the outlays, companies spent in the R+D sector, $1 \%$ for the purchase of licenses from the external sources, $2 \%$ preserved for the marketing connected with the introduction of new or highly improved products and $1 \%$ for the trainings of the staff directly linked with the implementation of the innovation (Figure 3).

Figure 3. Innovative activity of Polish industrial enterprises in 2011

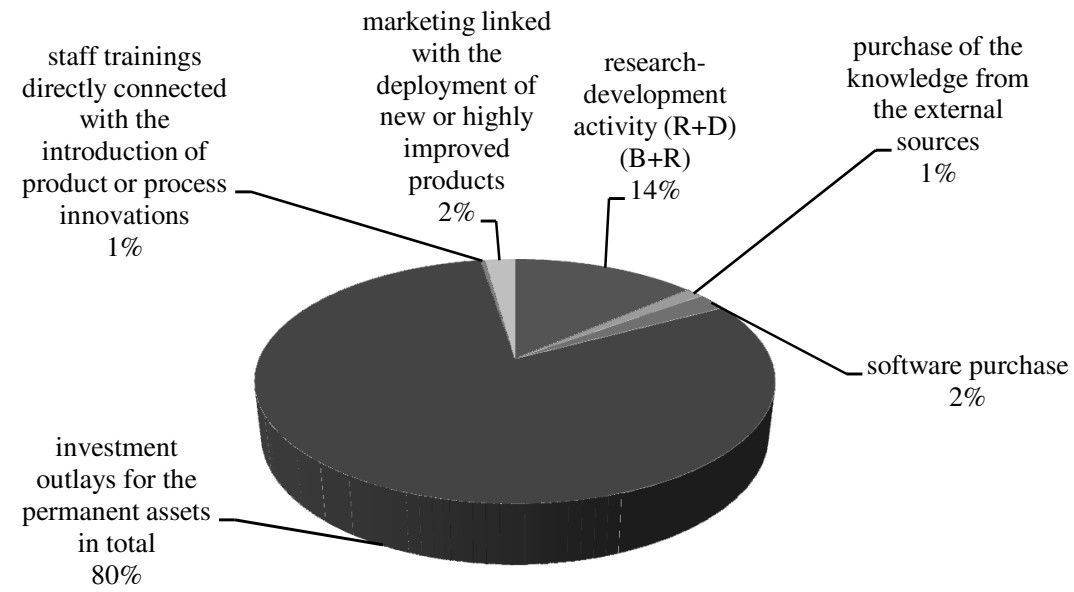

Source: Own elaboration on the basis of Science and Technology, Innovative Activity, Local data Bank of the Central Office of Statistics.

The structure of the financial outlays for the innovative activity in 2011 did not change in relation to 2010 (Figures 3 and 4). 
Figure 4. Innovative activity of Polish industrial enterprises in 2010

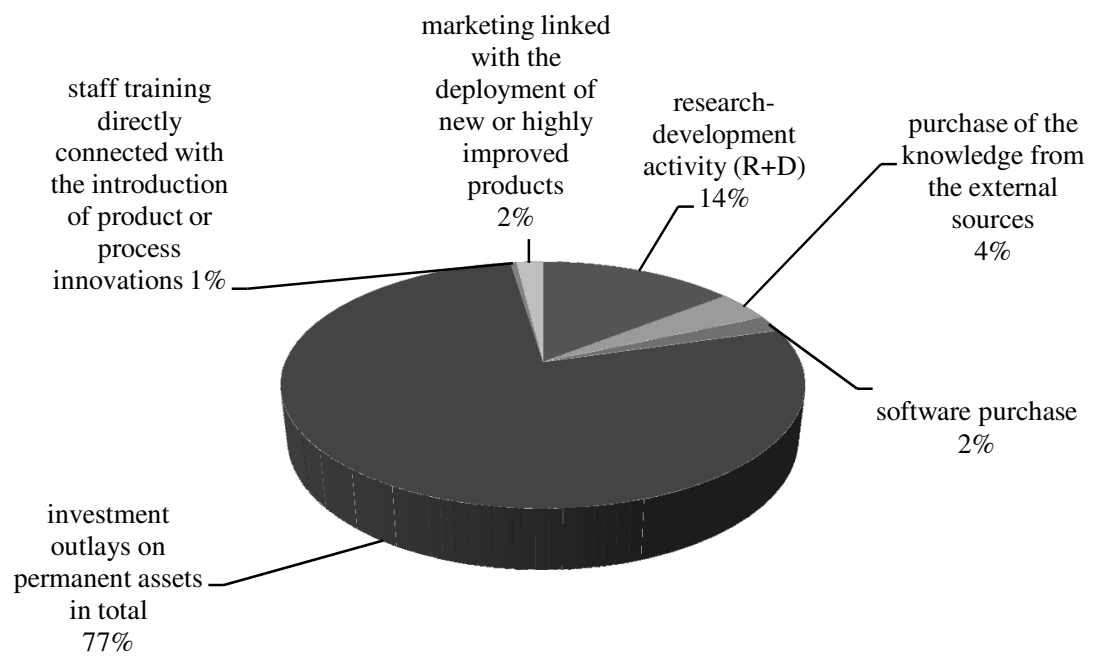

Source: Own elaboration on the basis of Science and Technology, Innovative Activity, local data Bank of the Central Office of Statistics.

In 2010 and 2011 the predominant part of the financial outlays for the innovative activity was reserved for the investments in machines, equipment and devices. However, a noticeable decrease of the outlays for the purchase of knowledge from the external sources was observed from $4 \%$ in $2010.1 \%$ in 2011. It may be credible evidence for the decline of enterprises engagement in technology transfer. It seems ambiguous since possessing technologies from the outside provides more possibilities of introducing innovations, rather than other forms of innovative activities.

Due to the size category of the enterprises, in accordance with the Central Office of Statistics, only 6,31\% of small industries preserved financial outlays for the innovative activity. In the group of medium companies $-24,54 \%$ and in the group of big companies $-54,16 \%$.

Analysing financial outlays for the innovative activity, the attention should be drawn to the sources where the financial outlays come from. 
Figure 5. Sources of financing innovative activities of industrial enterprises in 2011

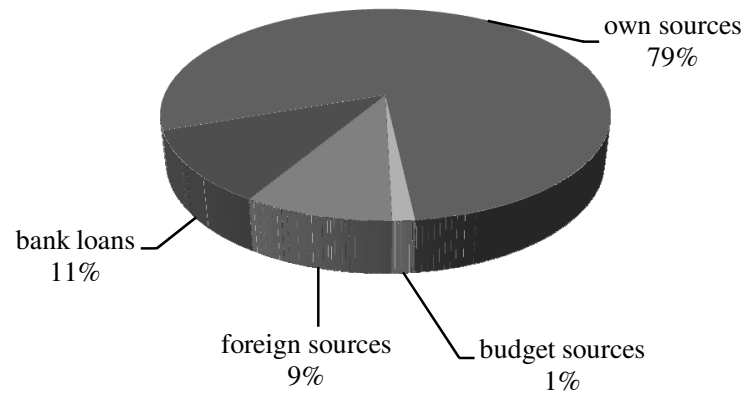

Source: Own elaboration on the basis of Science and Technology, Innovative Activity, Local Data Bank of the Central Office of Statistics.

The major source of financing innovative activity in 2011 in the industrial enterprises were the own financial sources which constituted over $79 \%$ of the outlays. Less frequently the means of financing were the money acquired from the state budget.

In case of the technology transfer, Polish industrial enterprises in 2011 most often purchased technologies originating from Poland in a form of acquired licenses. The highest number of licenses bought abroad came from the countries of the European Union and the United States. Polish industrial enterprises also relatively frequently bought automation sources, and to a smaller extent consulting services and research-development works. In 2011 the highest number of enterprises sold new technologies in Poland. In case of the sale to the European Union countries, the most often sold were research-development works, whereas the items sold to the remaining countries were often automation sources, and to the countries from outside the European Union licences, automation sources and consulting services were sold. Bearing in mind the size class of the subjects, it is noticeable that almost $40 \%$ of the national licenses and nearly $60 \%$ of the foreign were used by the enterprises employing more than 249 workers. Considering the sale of technologies in Poland, in territorial terms, it can be observed that the sale of licences and automation sources was conducted by the majority of the enterprises from wielkopolskie and research-development works from malopolskie region. The consulting services sale and remaining technologies were led by the subjects from mazowieckie and malopolskie areas. 


\section{Conclusions}

Despite the key role played by the industrial enterprises, their engagement in the process of building economy based on knowledge is considered to be insufficient. The level of innovativeness of enterprises measured by the number of innovative companies introducing innovations is far from the expectations. The amount of deployed innovations is particularly low in case of small and medium enterprises.

Polish industrial enterprises rather rarely use external sources of innovations. Small and medium enterprises are not interested in this type of activity, or do not possess adequate potential for its conduction. Moreover, small and medium companies less often introduce innovations and less eagerly bear the risk connected with the implementation of the innovation. In addition, they frequently do not have qualified human resources and managerial staff, as well as sufficient financial resources. It seems legitimate to claim that the reason for the low innovativeness of small and medium companies lies in the low awareness of the need of being innovative and the reluctance to take risks. The exception are enterprises employing over 249 people, which more eagerly engage in the innovative activities based on the authorial works of $\mathrm{R}+\mathrm{D}$ branches and additionally decide on taking higher financial outlays on the innovative activity. It can be caused by the fact that they generally operate in the conditions of highly demanding competition. They often operate in international markets and are forced to introduce products highly innovative, that is, products coming from external sources. Demanding markets, operations of big enterprises and the presence of strong competition both on the national and international scale force them to hold the position by introduction of innovations. What is entirely visible is the regularity that the bigger the enterprise is, the most often innovation is deployed. It results from the fact that those companies possess higher potential for the conduction of innovative activity. Big companies also have better financial possibilities and better access to qualified managerial staff which in general is more aware of the needs of innovations. Those enterprises are more eager to take the risk connected with the innovation process.

The greatest category of the financial outlays in Polish industrial enterprises constitute investment outlays. It may indicate the low innovative potential and constant need of modernization. Technology transfer objectified in the form of machines and equipment does not significantly influence the innovative potential of enterprises.

The phase of the development of small and medium enterprises shows lack of possibilities of the active participation in the process of innovative activities initiation within the enterprise resources. The level of small and medium companies innovativeness depends on the scale of innovation 
spread. Such a possibility is ensured by the technology transfer. It seems that the level of the influence of the mechanisms of the technology transfer on the innovations implementation is insufficient. The potential increase of the innovation level which should be gained is implicated by the current forms of technology transfer, occurring within the enterprises. Polish companies, particularly from the small and medium sector very often cannot use the possibilities which are given by the technology transfer. Effective use of the mechanism of the technology transfer in particular enterprises or branches provide an opportunity for the competitiveness improvement of the enterprises through the increase of their abilities of being innovative, which in fact constitutes their competitiveness. That is the technology transfer which gives the companies the possibility to increase their competitiveness with the simultaneous dedication of less financial outlays and without taking the risk. The advantage of the external sources is the rapid acquirement of a technical solution, relatively lower costs and significantly lower risk level than in the case of internal innovation sources. At the same time, technology transfer from the outside is easier and undeniably uses less expensive methods of growing innovativeness in Polish industrial enterprises.

\section{References}

Bank Danych Lokalnych, Główny Urząd Statystyczny, http://www.stat.gov.pl/bdl/ app/dane_podgrupp.hier?p_id=367997\&p_token=-682269318 (28.02.2013).

Głodek P.P., Gołębiewska M. (2006), Transfer technologii w matych i średnich przedsiębiorstwach, SOOIPP, Warszawa.

Innowacyjność 2010 (2010), Polska Agencja Rozwoju Przedsiębiorczości, Warszawa.

Janasz W., Janasz K., Świadek A., Wiśniewska J. (2001), Strategie innowacyjne przedsiębiorstw, Wydawnictwo Naukowe Uniwersytetu Szczecińskiego, Szczecin.

Lunguis G. (2003), A rich vision of Technology Transfer. Technology Value Management, Journal of Technology Transfer, 28, Kluwer Academic Publishers.

Mansfield E. (2002), Podstawy makroekonomii, zasady, przyktady, zadania, Placet, Warszawa.

Nauka i technika w 2011r. (2012), Główny Urząd Statystyczny, Warszawa.

Niedzielski PP., Markiewicz J., Rychlik K., Rzewuski T. (2007), Innowacyjność $w$ dziatalności przedsiębiorstw. Kompendium wiedzy, Wydawnictwo Naukowe Uniwersytetu Szczecińskiego, Szczecin.

Penc J. (1999), Innowacje i zmiany w firmie, Placet, Warszawa.

Schumpeter J. (1960), Teoria rozwoju gospodarczego, PWN, Warszawa. 
The Global Competitiveness Report 2012-2013 (2012), World Economic Forum, Geneva.

Zasady gromadzenia i interpretacji danych dotyczacych innowacji. Pomiar działalności naukowej i technicznej (2005), OECD and Eurostat Oslo Manual 